\title{
KETERLIBATAN JARINGAN SOSIAL DALAM PROSES PENEMUAN BISNIS
}

\author{
Krismi Budi Sienatra \\ Fakultas Manajemen dan Bisnis, Universitas Ciputra \\ Alamat surel : krismi.budi@ ciputra.ac.id
}

\begin{abstract}
The research analyzes the involvement of social network, that is family, friends, and experts formed by entrepreneur for the success of the entrepreneurship process at business discovery phase. Ciputra University students are the population for the study. Sixty students at the second semester are used as the sample. At this semester students are taught to find business idea and to pioneer its establishment. This research uses regression logistics to predict the success of business discovery phase. The results show family members, college friends, friends in group and other friends, and skill encourage success at the discovery and emergence of business phase. Experts do not have impact at the discovery phase and the establishment of a new business.
\end{abstract}

Keywords: social network, entrepeneurship, business discovery

\begin{abstract}
Abstrak
Penelitian ini mempelajari keterlibatan jaringan sosial yaitu keluarga, teman, dan pakar yang dibentuk oleh wirausaha dalam kesuksesan proses kewirausahaan pada fase penemuan bisnis. Subyek penelitian ini adalah mahasiswa Universitas Ciputra, yang mengedepankan pada pembelajaran kewirausahaan, sebagai populasi. Sampel yang digunakan sebanyak 60 orang mahasiswa Universitas Ciputra yang berada di semester dua. Pada semester dua para mahasiswa diajarkan untuk menemukan gagasan bisnis dan merintis pendirian usaha yang digagas tersebut. Penelitian ini menggunakan regresi logistik untuk memprediksi kesuksesan fase penemuan bisnis. Hasil penelitian menunjukkan anggota keluarga, teman kuliah, teman dalam kelompok, teman diluar kampus dan ketrampilan mendorong kesuksesan pada fase penemuan dan kemunculan usaha bisnis. Pakar tidak memiliki dampak pada fase penemuan dan pendirian usaha bisnis.
\end{abstract}

Kata kunci: jaringan sosial, kewirausahaan, penemuan business

\section{PENDAHULUAN}

Keluarga merupakan lingkaran terdalam dalam sebuah komunitas. Begitu pula ketika dalam proses penggagasan dan perintisan usaha bisnis keluarga memegang peranan penting sebagai pihak pertama yang memberikan saran dan pendapat. Penelitian ini menyelidiki keterlibatan anggota keluarga dalam proses kewirausahaan dari perspektif jaringan kewirausahaan (Araujo dan Easton, 1996). Beberapa penelitian telah difokuskan pada memeriksa peranan anggota keluarga dalam keputusan bisnis (Greve dan Salaff, 2003) akan tetapi masih sangat sedikit penelitian yang dilakukan secara berkelanjutan. Habbershon dan Williams (1999) dalam risetnya yang paling awal tentang pengamatan keterkaitan keluarga dan bisnis merangkum konsep keluarga dalam bisnis didefinisikan sebagai "ikatan bisnis unik sumber daya yang memiliki interaksi sistem antara keluarga, anggota individu, dan bisnis". Dengan demikian, peran keluarga dalam proses perintisan kewirausahaan memerlukan penyelidikan lebih lanjut. Pertama, penelitian ini dilakukan agar perlu lebih banyak pengetahuan tentang apakah dan bagaimana keterlibatan anggota keluarga selama proses kewirausahaan. Kedua, untuk memerlukan pengetahuan tentang apa saja keterlibatan keluarga yang memengaruhi proses kewirausahaan dan apa yang mencirikan hubungan mereka dengan pengusaha.

Keluarga, teman, dan afiliasi merupakan bentuk dari jaringan sosial. Jaringan sosial adalah kunci untuk membuka dan mendapatkan akses ke sumber lain karena mereka memfasilitasi komunikasi antara orang-orang yang memiliki hubungan jaringan (Anderson et al., 2007). Jaringan 
yang baik berdasarkan lemah atau kuat frekuensi kontak yang terjadi terkait dengan hubungan timbal balik. Danes et al. (2009) mengatakan hubungan dengan teman-teman dan keluarga yang dikategorikan sebagai ikatan yang kuat karena sering terjadinya kontak dan kedekatan emosional. Sebaliknya, hubungan antara rekan bisnis, konsultan, dan kontak lain diklasifikasikan sebagai ikatan lemah karena kontak yang kurang sering terjadi. Robinson (2011) juga berpendapat bahwa kuat lemahnya ikatan terkait dengan keragaman sumber pengetahuan dan saran dalam memberikan informasi serta mengeksekusi informasi tersebut dalam aktivitas. Namun, frekuensi kontak dalam keluarga dan teman belum tentu cukup sebagai satu-satunya ukuran kualitas jaringan karena pertukaran informasi yang berguna tidak dijamin hanya ada kesempatan untuk pertukaran dalam jaringan sosial (Robinson, 2011). Misalnya, ikatan yang kuat dengan teman atau anggota keluarga dengan siapa berinteraksi sering tidak selalu berguna dalam pengaturan bisnis, sedangkan ikatan yang lemah dengan konsultan bisnis ataupun pihak formal akan diharapkan menghasilkan informasi yang lebih berguna khususnya dalam proses eksekusi bisnis.

Nebus (2007) berpendapat bahwa situasi yang paling menguntungkan adalah di mana kontak sosial yang terjadi menjadi lebih ahli karena kontak sosial lebih mudah untuk diakses dan lebih mungkin untuk berkomunikasi. Sebaliknya, para ahli yang mungkin lebih memiliki informasi yang berharga, tetapi lebih sulit diakses yang akan menghambat proses penggagasan. Bersosialisasi secara informal bisa menjadi lebih penting untuk membangun modal sosial dan akhirnya berdampak pada pertumbuhan bisnis (Bowey dan Easton, 2007). Dalam pemaparan diatas terlihat bahwa penggunaan jaringan sosial dengan ikatan yang kuat baik keluarga dan teman hingga jaringan dengan ikatan yang lemah seperti para ahli atau pakar professional memiliki kontribusi terhadap proses bisnis individu yang berinteraksi pada ikatan tersebut.

$$
\text { Universitas Ciputra adalah }
$$
universitas yang mengedepankan proses kewirausahaan dalam pembelajarannya. Mahasiswa Universitas Ciputra dididik dalam kewirausahaan agar ketika lulus dapat menjadi lulusan yang telah memiliki usaha. Proses pembelajaran kewirausahaan di Universitas Ciputra terdiri dari beberapa tahapan dari semester satu hingga semester tujuh. Tahapan dalam penggagasan dan penemuan bisnis terjadi ketika mahasiswa menginjak pada semester dua, sehingga peneliti ingin mengetahui sejauh mana faktor keluarga, teman, dan jaringan formal membantu dalam proses penggagasan dan penemuan bisnis.

\section{TINJAUAN PUSTAKA}

Jaringan sosial wirausaha dan hubungannya antar orang-orang di dalam jaringan memiliki peran berbeda. Mereka dapat menjadi anggota keluarga, teman saat ini atau mantan rekan, koneksi bisnis dan sebagainya. Peran spesifik dari keluarga masih kekurangan bukti untuk diteliti dan masih agak kabur. Dyer (2003) berpendapat dari tinjauan literatur bahwa organisasi yang berbasis kekerabatan memengaruhi tata kelola, keunggulan kompetitif, perumusan strategi, budaya organisasi, modal sosial, tim, konflik, kepemimpinan, sukses, pengembangan karir, dan perubahan dalam organisasi melalui tujuan dan nilai-nilai keluarga. Dyer (2003) juga mengamati bahwa keluarga dan kekerabatan sebagai peubah sangat banyak diabaikan dalam penelitian organisasi. Selanjutnya, Stewart (2002) berpendapat bahwa literatur tentang keluarga dan kekerabatan dalam antropologi adalah sumber pengetahuan yang bisa dimanfaatkan untuk bidang penelitian bisnis keluarga.

Hasil penelitian tentang jaringan kewirausahaan oleh Aldrich et al. (2002) melaporkan bahwa 65 persen dari semua subyek penelitian melibatkan hubungan pasangan / partner, ikatan keluarga lainnya atau keduanya dalam menjalankan bisnis. Lebih lanjut, Aldrich dan Cliff (2003) mengamati bahwa memulai bisnis sering terjadi merupakan tanggapan dari dorongan dalam hubungan keluarga ketimbang pemikiran rasional, pengembangan dan eksploitasi peluang bisnis. Dalam studi 
Kirkwood (2007) ditemukan bahwa orang tua memainkan peran penting dalam penciptaan usaha baru. Oleh karena itu, Aldrich dan Cliff (2003) berpendapat untuk kebutuhan dari perspektif keluarga tertanam pada kewirausahaan, menyiratkan bahwa peneliti menggabungkan keluarga dan anggota keluarga ke dalam model konseptual.

Birley (1985) menyimpulkan bahwa kontak bisnis formal yang paling bermanfaat ketika pengusaha yang mencari keuangan, sedangkan keluarga, teman dan sejawat tampaknya menjadi sumber utama dalam memberikan ide, memobilisasi bahan baku, pemasok, peralatan, ruang, karyawan, dan perintah. Davidsson dan Honig (2003) menemukan bahwa dengan hubungan jaringan internal seperti memiliki orang tua dan / atau teman-teman dekat atau tetangga dalam bisnis, serta dorongan dari teman dan keluarga, sangat terkait dengan ketermungkinan kesuksesan perintisan bisnis. Demikian pula, Greve dan Salaff (2003) menemukan bahwa wirausahawan yang memiliki orang tua yang berbisnis lebih mungkin berhasil dibandingkan orang lain yang orang tuanya adalah pekerja. Keluarga selama proses kewirausahaan pada dasarnya masih belum diketahui sejauh mana anggota keluarga benar-benar mengambil bagian selama proses kewirausahaan.

Kajian dari Evald et al. (2006) berpendapat bahwa anggota keluarga mungkin memiliki pengaruh hanya pada kegiatan tertentu di proses kewirausahaan. Hasil ini tidak runtut dengan penelitian Greve dan Salaff (2003) sehingga mendorong penyelidikan lebih lanjut ke dalam peran anggota keluarga selama proses kewirausahaan. Peran anggota keluarga pada bagian tertentu selama proses kewirausahaan pada dasarnya masih belum diketahui serta sejauh mana anggota keluarga benar-benar turut mengambil bagian selama proses kewirausahaan. Oleh karena itu penelitian ini dilakukan untuk melihat peran keluarga dalam proses kewirausahaan dengan dibatasi pada proses penemuan bisnis saja.

Penelitian terdahulu yang dilakukan Kyvler (2007) dan Saraf (2015) menyelidiki faktor-faktor apa saja yang menyebabkan timbulnya niatan berwirausaha. Kyvler (2007) melakukan penelitian di negaranegara Eropa dan menemukan hasil keluarga, teman (lingkar dalam dan lingkar luar), dan para ahli atau pakar mempunyai peran dalam timbulnya niatan berwirausaha. Hasil ini diikuti dengan temuan yang konsisten dan sama tentang peran orang tua oleh Kirkwood (2007). Dari hasil kajiankajian terdahulu yang dilakukan dan kajian pustaka pada penjelasan sebelumnya maka hipotesis dalam penelitian ini adalah :

H1 : keluarga berpengaruh terhadap proses penemuan bisnis.

$\mathrm{H} 2$ : teman kuliah berpengaruh terhadap proses penemuan bisnis.

$\mathrm{H} 3$ : teman luar berpengaruh terhadap proses penemuan bisnis.

$\mathrm{H} 4$ : teman kelompok berpengaruh terhadap proses penemuan bisnis

H5 : pakar berpengaruh terhadap proses penemuan bisnis

Saraf (2015) melakukan penelitian di India tentang faktor-faktor yang menyebabkan timbulnya niatan berwirausaha dan memfokuskan pada modal kewirausahaan dan menemukan hasil ketrampilan, kemampuan melihat peluang, dan keberanian terhadap risiko memiliki peran terhadap niatan berwirausaha. Dari hasil tersebut maka hipotesis keenam dalam penelitian ini adalah sebagai berikut :

H6 : ketrampilan berpengaruh terhadap proses penemuan bisnis 


\section{METODE PENELITIAN}

Pendekatan siklus hidup berguna untuk menjelaskan perilaku khususnya di jaringan sosial sesuai dengan tahapan proses pembentukan. Proses kewirausahaan menurut Global Entrepreneurship Monitor diwakili oleh empat tahap seperti yang diperlihatkan Gambar 1:

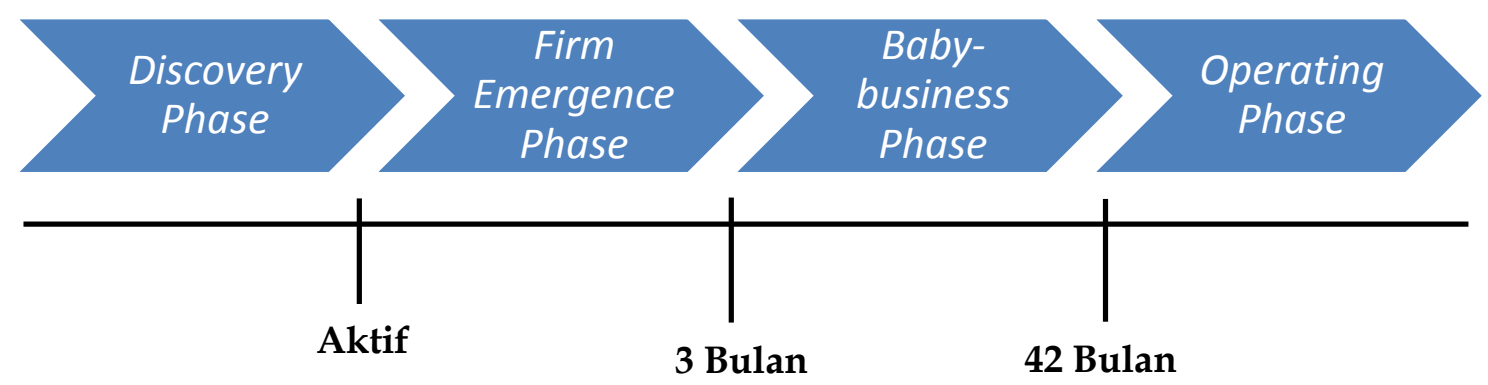

Sumber: Global Entrepreneurship Monitor

Gambar 1. Fase Siklus Hidup Bisnis

Keaktifan adalah faktor yang membedakan fase penemuan dengan fase munculnya perusahaan. Wirausaha di fase penemuan memiliki niat untuk memulai bisnis dalam tiga bulan namun tidak aktif berusaha untuk memulai. Munculnya perusahaan dianggap telah terjadi ketika wirausaha telah mengambil langkahlangkah aktif untuk membangun sebuah bisnis tetapi belum mendapatkan pemasukan selama lebih dari tiga bulan. Pengusaha bergerak dari fase munculnya perusahaan menuju fase baby business setelah lebih dari tiga bulan tetapi tidak lebih dari 42 bulan. Akhirnya, ketika wirausaha telah beroperasi lebih dari 42 bulan mereka diklasifikasikan sebagai berada di fase operasi. Penelitian ini berfokus pada fase penemuan untuk melihat sejauh mana faktor jaringan sosial mampu memprediksi sukses dan tidaknya fase penemuan hingga fase munculnya perusahaan. Populasi dalam penelitian ini adalah mahasiswa Universitas Ciputra semester 2 yang dalam pembelajaran kewirausahaan pada tahapan penggagasan dan pendirian usaha dengan penggunaan sampel penelitian sebanyak 10 kali dari jumlah peubah prediktor yang sebanyak 6 (Hosmer dan Lemeshow, 2000) yaitu dengan jumlah sampel akhir 60 orang. Responden diberikan kuesioner berupa data nominal untuk mengisi peubah - peubah yang disajikan dalam bentuk pertanyaan.

Peubah dalam penelitian ini adalah identifikasi jaringan sosial, relasi anggota keluarga, kompetensi, dan proses kewirausahaan fase penemuan. Penelitian ini menggunakan regresi logistik dalam pengolahan datanya dimana proses kewirausahaan fase penemuan sebagai peubah tanggapan dan identifikasi jaringan sosial, relasi anggota keluarga serta kompetensi sebagai peubah prediktornya dengan persamaan : $\operatorname{Ln} \frac{F}{1-F}=\mathrm{a}+$ bkeluarga + bteman kuliah + bteman luar + bteman kelompok + bpakar + bketrampilan. Peubah keluarga, teman kuliah, teman luar, teman kelompok, dan pakar merupakan jumlah dari jaringan yang memberikan ide dan saran kepada responden serta ketrampilan merupakan indikator apakah tanggapan dan memiliki kecakapan dalam menjalankan bisnis. 


\section{Pemilihan Peubah}

Dari penelitian terdahulu yang ada pada jaringan kewirausahaan dan literatur tentang manfaat keberadaan keluarga dan wirausahawan, tiga fenomena umum tampaknya memengaruhi hasil tentang keterlibatan anggota keluarga menjadi jaringan sosial, yaitu :

Karakteristik Entrepreneur: pengusaha dengan karakteristik yang berbeda (misal: usia, jender, tingkat pendidikan atau nilainilai) cenderung melibatkan anggota keluarga dengan berbagai frekuensi. pengusaha yang berbeda mengalami tantangan yang berbeda dan karena itu mereka akan mengaktifkan jaringan sosial yang terdiri perbedaan di keterlibatan anggota keluarga.

Tabel 1. Peubah Penelitian

\begin{tabular}{|c|c|}
\hline Peubah & Pertanyaan \\
\hline Jaringan sosial keluarga & $\begin{array}{l}\text { Jumlah anggota keluarga yang membantu proses } \\
\text { penggagasan bisnis }\end{array}$ \\
\hline \multirow[t]{3}{*}{ Jaringan sosial teman } & $\begin{array}{l}\text { Jumlah teman dalam lingkungan universitas yang } \\
\text { membantu proses penggagasan bisnis dalam fase } \\
\text { penemuan }\end{array}$ \\
\hline & $\begin{array}{l}\text { Jumlah teman diluar lingkungan universitas yang } \\
\text { membantu proses penggagasan dalam fase } \\
\text { penemuan }\end{array}$ \\
\hline & $\begin{array}{l}\text { Jumlah teman dalam kelompok bisnis yang } \\
\text { membantu proses penggagasan dalam fase } \\
\text { penemuan }\end{array}$ \\
\hline Jaringan sosial formal & $\begin{array}{l}\text { Jumlah pakar atau ahli yang membantu proses } \\
\text { penggagasan dalam fase penemuan }\end{array}$ \\
\hline Karakteristik entrepreneur (kompetensi) & $\begin{array}{l}\text { Apakah anda memiliki pengetahuan, } \\
\text { ketrampilan, dan pengalaman dalam melakukan } \\
\text { bisnis }\end{array}$ \\
\hline Proses keberwirausahaan & $\begin{array}{l}\text { Dalam beberapa bulan ke depan, anda } \\
\text { mengharapkan untuk siap memulai bisnis baru }\end{array}$ \\
\hline
\end{tabular}

Sifat dari jaringan (Davidsson dan Honig, 2003; Evald et al., 2006) : sifat hubungan (misalnya ikatan kekuatan, diskusi, atau dorongan dan kritik) yang memprediksi keterlibatan anggota keluarga. Seorang entrepreneur yang memiliki hubungan yang kuat dari keluarga atau dia ingin mendapatkan dukungan emosional atau mendiskusikan isu-isu sensitif yang

\section{HASIL DAN PEMBAHASAN}

Penelitian ini menggunakan sampel sebanyak 60 orang mahasiswa yang memiliki jenis bisnis yang berbeda. Dari 60 orang mahasiswa yang dijadikan sampel, 60 persennya merupakan bisnis di bidang makanan dan minuman. Sebanyak 20 persen bergerak di bidang fesyen dan 30 persen kecenderungan untuk melibatkan anggota keluarga akan meningkat.

Dinamika proses kewirausahaan (Davidsson dan Honig, 2003; Evald et al., 2006; Greve dan Salaff, 2003) : dewasa ini secara umum entrepreneur mengembangkan berbagai tahapan proses kewirausahaan sebagai tantangan dan perubahan pengambilan keputusan.

sisanya bergerak dibidang jasa dan videography.

Pengujian hipotesis dilakukan dengan menggunakan regresi logistik untuk memprediksi tingkat keberhasilan dalam proses penemuan dan munculnya kewirausahaan. Di dalam regresi logistik perlu dilakukan uji kelayakan model yaitu likelihood, Cox and Snell's $R$ Square dan Nagelkerke $R$ Square, dan Hosmer and 
Lemeshow's Goodness of Fit. Kelayakan model regresi dinilai menggunakan Hosmer and Lemeshow's Goodness of Fit lebih besar daripada alpha $5 \%$ maka hipotesis nol tidak dapat ditolak dan berarti model mampu memprediksi nilai observasinya atau dapat dikatakan diterima sesuai dengan data observasinya (fit).

Tabel 2. Hosmer and Lemeshow Test

\begin{tabular}{lrrrr} 
Step & Chi-square & df & & \multicolumn{1}{c}{ Sig. } \\
\hline 1 & 8.496 & & 7 & .291 \\
\hline
\end{tabular}

Hasil Tabel 3 Omnibus Tests of Model Coefficients dengan nilai $\mathrm{p}$ value < alpha (0.05) memiliki arti paling tidak terdapat satu parameter regresi yang tidak sama dengan nol.

Tabel 3. Omnibus Tests of Model Coefficients

\begin{tabular}{|c|c|c|c|c|}
\hline & & Chi-square & $\mathrm{df}$ & Sig. \\
\hline \multirow[t]{3}{*}{ Step 1} & Step & 13.211 & 6 & .040 \\
\hline & Block & 13.211 & 6 & .040 \\
\hline & Model & 13.211 & 6 & .040 \\
\hline
\end{tabular}

Dari hasil uji regresi logistik pada Tabel 4 menunjukkan persamaan sebagai berikut :

Ln $\frac{F}{1-F}=5.828+0.35$ keluarga + 0.601 teman kuliah + 0.914teman luar - 1.378teman kelompok + 0.085pakar + 0.132 ketrampilan

Untuk melihat faktor-faktor prediktor yang menyebabkan kesuksesan dalam proses tahapan bisnis dilakukan uji parsial yang terletak dibawah ini :

Tabel 4 Tabel Hasil Uji Parsial

\begin{tabular}{|c|c|c|c|c|c|c|c|}
\hline & & Beta & S.E. & Wald & df & Sig. & Ket \\
\hline Step & Keluarga & .350 & .350 & 6.650 & 1 & .017 & Signifikan \\
\hline \multirow[t]{6}{*}{$1^{\mathrm{a}}$} & T.Kuliah & .601 & .381 & 6.484 & 1 & .015 & Signifikan \\
\hline & T.Luar & .914 & .362 & 6.387 & 1 & .011 & Signifikan \\
\hline & T.Kelompok & -1.378 & 1.044 & 7.143 & 1 & .007 & Signifikan \\
\hline & Pakar & .085 & .538 & .025 & 1 & .875 & Tidak Signifikan \\
\hline & Ketrampilan(1) & .132 & .285 & 4.421 & 1 & .040 & Signifikan \\
\hline & Constant & 5.828 & 5.025 & 1.346 & 1 & .246 & \\
\hline
\end{tabular}


Hasil signifikansi menunjukkan bahwa jumlah keluarga, jumlah teman kuliah, jumlah teman luar kuliah, jumlah teman dalam kelompok dan ketrampilan memiliki pengaruh terhadap kesuksesan proses penemuan dan munculnya perusahaan hal ini dibuktikan dengan nilai signifikansi yang lebih kecil dari alpha 0.05 sedangkan peubah pakar tidak berpengaruh terhadap kesuksesan proses penemuan dan munculnya perusahaan dalam proses kewirausahaan yang dibuktikan dengan nilai signifikansi yang lebih besar dari alpa 0.05 .

Tabel 5. Hasil R Square

\begin{tabular}{lrrr} 
Step & -2 Log likelihood & Cox \& Snell R Square & Nagelkerke R Square \\
\hline 1 & $19.297^{\mathrm{a}}$ & .232 & .486 \\
\hline
\end{tabular}

Hasil pada Tabel 5 yang menunjukkan hasil Nagelkerke $\mathrm{R}$ Square sebesar 0.486 berarti bahwa kemampuan peubah prediktor dalam menjelaskan peubah tanggapan adalah sebesar 48,6 \% dan terdapat $51,4 \%$ faktor lain diluar model yang menjelaskan peubah tanggapan.

Dari hasil pengujian analisis data memperlihatkan bahwa semakin banyak anggota keluarga yang memberikan ide dan saran kepada wirausaha akan membuat semakin sukses proses penemuan dan munculnya perusahaan. Hasil penelitian memberikan bukti bahwa banyak wirausaha memiliki anggota keluarga dalam jaringan sosial mereka selama proses kewirausahaan. Anggota keluarga dihitung sebagai yang paling berperan (Kyvler, 2007). Hampir 95 persen dari wirausaha dalam sampel penelitian memiliki setidaknya satu anggota keluarga dalam jaringan mereka. Disamping itu jaringan sosial selain anggota keluarga yaitu teman kuliah, teman luar kuliah, dan teman kelompok bisnis juga berpengaruh terhadap kesuksesan dalam fase penemuan dan munculnya perusahaan. Kowaleski et al. (2010) menyatakan bahwa perusahaan yang melibatkan keluarga memperoleh keuntungan dari sistem interaksi antara keluarga, anggota individu dan bisnis terkait keuntungan dalam konsep keberkeluargaan. Di sini, mereka mendapatkan dukungan emosional dalam periode yang menegangkan dalam menentukan penggagasan bisis bersama dan sumber daya keuangan yang diperlukan untuk memulai bisnis.

Pakar tidak berpengaruh terhadap kesuksesan dalam proses penemuan dan munculnya perusahaan. Hal ini wajar karena pakar adalah jaringan formal dalam sebuah ikatan modal sosial. Wirausaha umumnya kurang membutuhkan informasi pada fase penemuan karena kepercayaan yang dibangun masih minim. Namun, sebagai pengusaha yang bergerak maju dalam proses kewirausahaan dari fase munculnya perusahaan melalui fase baby business hingga menuju fase operasi, mereka menghadapi keputusan tentang pertumbuhan, pengembangan bisnis, internasionalisasi dan seterusnya. Perilaku wirausaha menjadi lebih berbeda dan mereka memerlukan akses ke informasi pasar yang banyak. Dengan demikian, mereka kurang mengandalkan pada anggota keluarga ditahap selanjutnya dari proses kewirausahaan. Dalam fase baby business hingga operasi inilah peran pakar baru akan tampak. Penelitian ini menunjukkan, di satu sisi, bahwa perbedaan antara ikatan lemah dan ikatan kuat anggota keluarga terhadap anggota bukan keluarga misalnya pemanfaatan pakar adalah tentang masalah keseimbangan dalam memberikan masukan dan ikatan kuat dan lemah mengambil peran yang berbeda selama proses kewirausahaan (Aldrich dan Cliff, 2003).Sehingga memerlukan penelitian lebih lanjut perlu memeriksa peran jaringan formal dan informal dalam fase kewirausahaan selanjutnya. 


\section{SIMPULAN}

Hasil empiris menunjukkan bahwa kesuksesan proses kewirausahaan pada fase penemuan dan munculnya perusahaan dipengaruhi oleh keterlibatan anggota keluarga, teman kuliah, teman kelompok, teman diluar kuliah, dan ketrampilan. Pakar diluar dugaan tidak memiliki dampak pada proses kewirausahaan pada fase penemuan dan munculnya perusahaan. Hal utama mengapa kesuksesan pada tahap penemuan bisnis dan munculnya usaha dipengaruhi oleh keluarga dan teman-teman adalah karena kepercayaan yang dibangun oleh wirausahawan dan ikatan emosional dalam berbagi ide dan saran. Para wirausahawan lebih memiliki kepercayaan terhadap jaringan internal berupa keluarga dan teman dari pada jaringan ekternal berupa pakar atau ahli professional. Pakar akan memiliki peran yang berbeda dalam kelangsungan bisnis namun tidak pada fase penemuan dan munculnya perusahaan. Hal yang menjadi utama mengapa penelitian ini meneliti tentang penemuan ide bisnis disebabkan karena dalam memulai sebuah bisnis hal yang paling utama adalah tentang ide apa yang ditemukan untuk memulai sebuah bisnis. Sering kali seorang mahasiwa ingin bercita-cita menjadi seorang pengusaha namun ketika diajukan pertanyaan tentang ide mereka untuk memulai bisnis, mereka sering kali tidak tahu menjawab apa atau bahkan tidak memiliki ide sama sekali tentang bisnis apa yang akan dilakukan. Dari fenomena tersebut penelitian ini dilakukan guna ingin mengetahui darimana saja ide-ide tentang bisnis dapat muncul.

\section{Keterbatasan penelitian}

Penelitian ini memberikan

kontribusi terhadap pengetahuan tentang keterlibatan anggota keluarga dalam proses kewirausahaan dengan keterbatasan berikut. Pertama, ada keterbatasan mengenai penyelidikan empiris ini dilakukan tanpa ukuran kinerja. Analisis anggota keluarga yang mengambil bagian dalam proses kewirausahaan tidak diketahui apakah proses keterlibatan tersebut benar-benar meningkatkan atau cenderung membatasi wirausahawan. Kedua, konsep anggota keluarga ditafsirkan secara subjektif oleh setiap responden. Responden mungkin menganggap keluarga dan anggota keluarga secara berbeda. Beberapa responden mungkin hanya menganggap anggota keluarga inti, sedangkan yang lain mungkin juga telah disertakan lebih kerabat keluarga jauh. Fakta ini didukung dengan terdapat responden yang menyertakan bahwa jumlah anggota keluarga yang terlibat sebanyak sepuluh orang. Selanjutnya, konsep keluarga bisa saja dibagi menjadi sub kategori anggota keluarga besar seperti orang tua, saudara kandung, anak-anak, dan hubungan keluarga yang lebih jauh. Ketiga, penelitian ini menawarkan prediksi yang memengaruhi kesuksesan dalam tahap menjalankan bisnis hanya pada fase penemuan bisnis. Selanjutnya penelitian dapat meneliti fase selanjutnya setelah fase penemuan yaitu fase firm emerging phase, baby business, dan operating.

\section{DAFTAR PUSTAKA}

Aldrich, H.E., Carter, N.M. and Ruef, M. (2002). With very little help from their friends: genderand relational composition of nascent entrepreneurs' startup teams", in Bygrave, W.D.,

Brush, C.G., Davidsson, P. et al. (Eds), Frontiers of Entrepreneurship Research 2002, Center for Entrepreneurship Research, Babson College, Wellesley, MA, pp. 15669.

Aldrich, H.E. and Cliff, J.E. (2003). The pervasive effects of family on entrepreneurship: toward a family embeddedness perspective, Journal of Business Venturing, Vol. 18, pp. 573-96

Anderson, A. and J. Park. (2007). Entrepreneurial social capital Conceptualizing social capital in new high-tech firms. International Small Business Journal, 25(3), 245272. 
Araujo, L. and Easton, G. (1996). Networks in Socioeconomics Systems, in Iacobucci, D. (Ed.), Networks in Marketing, Sage Publications, Thousand Oaks, CA, pp. 63-107.

Birley, S. (1985), The Role of Networks in The Entrepreneurial Process, Journal of Business Venturing, Vol. 1, pp. 107-17.

Bowey, J. L. and G. Easton. (2007). Entrepreneurial social capital unplugged - An activity-based analysis. International Small Business Journal, 25(3), 273-306.

Dyer, G. (2003). The family: the missing variable in organizational research. Journal Entrepreneurship Theory and Practice, Vol. 27 No. 4, pp. 401-16.

Davidsson, P. and Honig, B. (2003). The Role Of Social And Human Capital Among Nascent Entrepreneurs, Journal of Business Venturing, Vol. 18 No. 3, pp. 301-31.

Danes, S.M., Stafford, K., Haynes, G. and Amarapurkar, S. (2009). Family capital of family firms: bridging human, social, and financial capital. Journal Family Business Review, Vol. 22 No. 3, pp. 199-215.

Evald, M.R., Klyver, K. and Svendsen, S.G. (2006).The Changing Importance Of The Strength Of Ties Throughout The Entrepreneurial Process. Journal of Enterprising Culture, Vol. 14 No. 1, pp. 1-26.

Greve, A. and Salaff, J.W. (2003).Social Networks And Entrepreneurship Journal Entrepreneurship Theory and Practice, Vol. 28 No. 1, pp. 122.

Habbershon, T.G. and Williams, M.L. (1999). A Resource-Based Framework For Assessing The Strategic Advanges Of Family Firms. Journal Family Business Review. Vol. 12 No. 1, pp. 1-25.

Hosmer, D.W. and Lemeshow, S. 2000. Applied Logistic Regression $2^{\text {nd }}$. New York : John Wiley \& Sons, Inc.

Kirkwood, J. (2007). Igniting The Entrepreneurial Spirit: Is The Role
Parents Play Gendered ?.

International Journal of

Entrepreneurial Behaviour \&

Research, Vol. 13 No. 1, pp. 39-59.

Klyver, Kim. (2007). Shifting Family Involvement During The Entrepreneurial Process, International Journal of Entrepreneurial Behavior \& Research, Vol. 13 Iss 5 pp. 258 277

Kowalewski, O. Talavera, and O., and Stetsyuk, I. (2010). Influence of Family Involvement in Management and Ownership on Firm Performance: Evidence From Poland. Journal Family Business Review, Vol 23(1), pp 45- 59

Nebus, J. (2007). Building Collegial Information Networks: A Theory Of Advice Network Generation. Journal Academy of Management Review, 31(3), 615-637

Robinson, Sherry. (2011). Social Networks And Entrepreneurial Growth, International Journal of Management \& Information Systems - Fourth Quarter 2011, Vol. 15, No. 4 , pp. $65-70$

Saraf. (2015). What Determines Entrepreneurial Intention in India?. Journal of Entrepreneurship and Innovation in Emerging Economies. Vol 1, No 1, pp 39-55

Stewart, A. (2003), Help One Another, Use One Another: Toward An Anthropology Of Family Business, Journal Entrepreneurship Theory \& Practice, Vol. 27 No. 4, pp. 383-96. 